\title{
CATION EXCHANGE PROCESS FOR \\ MOLTEN SALT EXTRACTION RESIDUES
}

Stephen G. Proctor

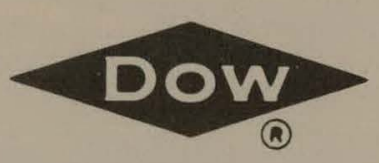

DOW CHEMICAL U.S.A. ROCKY FLATS DIVISION

P. O. BOX 888

GOLDEN, COLORADO 80401

U. S. ENERGY RESEARCH AND DEVELOPMENT ADMINISTRATION CONTRACT AT(29-1)-1106 


\section{DISCLAIMER}

This report was prepared as an account of work sponsored by an agency of the United States Government. Neither the United States Government nor any agency Thereof, nor any of their employees, makes any warranty, express or implied, or assumes any legal liability or responsibility for the accuracy, completeness, or usefulness of any information, apparatus, product, or process disclosed, or represents that its use would not infringe privately owned rights. Reference herein to any specific commercial product, process, or service by trade name, trademark, manufacturer, or otherwise does not necessarily constitute or imply its endorsement, recommendation, or favoring by the United States Government or any agency thereof. The views and opinions of authors expressed herein do not necessarily state or reflect those of the United States Government or any agency thereof. 


\section{DISCLAIMER}

Portions of this document may be illegible in electronic image products. Images are produced from the best available original document. 


\section{LEGAL NOTICE}

This report was prepared as an account of work sponsored by the United States Government. Neither the United States nor the Energy Research and Development Administration, nor any of their employees, nor any of their contractors, subcontractors, or their employees, miakes any warranty, expressed or implied, or assumes any legal liability or responsibility for the accuracy, completeness or usefulness of any information, apparatus, product or process disclosed, or represents that its use would not infringe privately owned rights.

Printed in the United States of America

Available from the National Technical Information Service

U. S. Department of Commerce

Springfield, Virginia 22151

Price: Printed Copy $\$ 4.00$ Microfiche $\$ 2.25$ 
- NOTICE

This report was prepared as an account of work sponsored by the United States Government. Neither the United States nor the United States Energy Research and Development Administration, nor any of their employees, 'nor any of their contractors, subcontractors, or their employees, makes any warranty, express or implied, or assumes any legal lability or responsibility for the accuracy, completeness or usefulness of any information, apparatus, product or process disclosed, or represents that its use would not infringe privately owned rights.
CATION EXCHANGE PROCESS FOR

\section{MOLTEN SALT EXTRACTION RESIDUES}

Chemistry Research and Development

PROCESS CHEMISTRY

\section{SUBJECT DESCRIPTORS}

Plutonium Americium Molten Salt Residues Ion Exchange Recovery

DOW CHEMICAL U.S.A.

ROCKY FLATS DIVISION

P. O. BOX 888

GOLDEN, COLORADO 80401

Prepared under Contract AT(29.1)-1106

for the

Albuquerque Operations Office

U.S. Energy Research and Development Administration 
CONTENTS

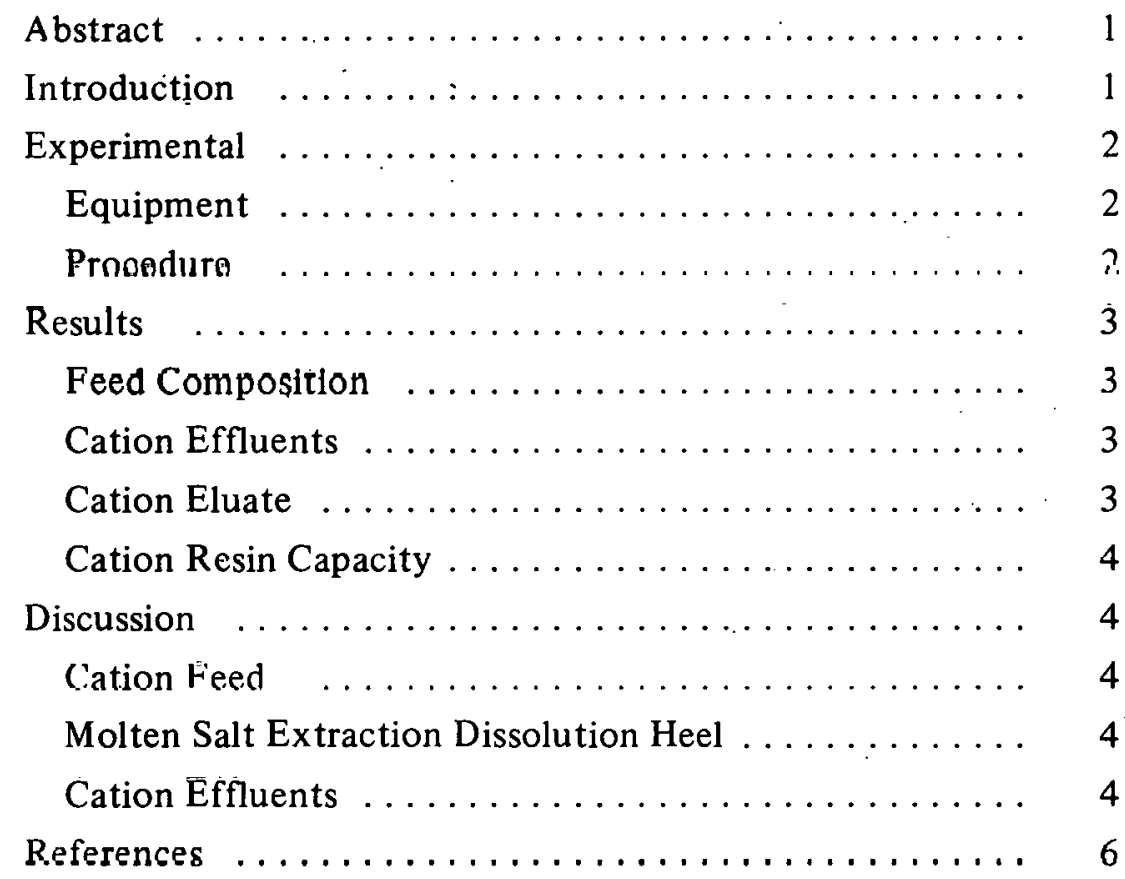




\title{
CATION EXCHANGE PROCESS FOR MOLTEN SALT EXTRACTION RESIDUES
}

\author{
Stephen G. Proctor
}

\begin{abstract}
A new method, utilizing a cation exchange technique, has been developed for processing molten salt extraction (MSE) chloride salt residues. The developed ion exchange procedure has been used to separate americium and plutonium from gross quantities of magnesium, potassium, and sodium chloride that are present in the residues. The recovered plutonium and americium contained only 20 percent of the original amounts of magnesium, potassium, and sodium and were completely free of any detectable amounts of chloride impurity.
\end{abstract}

\section{INTRODUCTION}

A molten salt extraction (MSE) process ${ }^{1}$ is used at Rocky Flats to extract americium from plutonium metal. Americium-241 is present in the metal as a result of the radiolytic decay of plutonium-241, which is present in plutonium stream material. The MSE process extracts a small amount of plutonium in addition to àmericium; therefore, the MSE residue must be processed to recover both the plutonium and americium. The americium recovery is desirable because of the high value placed on americium and because of its increased usage by a variety of industries. The recovered americium dioxide is currently sent to the Oak Ridge National Laboratory's (ORNL) Isotopes Pool for distribution.

Rocky Flats routinely had been processing MSE residues using a hydroxide precipitation process, ${ }^{2}$ which required many process-operator manipulations. This resulted in the operators being potentially subjected to high radiation exposure from the americium-241. In addition, the process yielded a plutonium-americium hydroxide precipitate that was ligh in chloride contamination. The chloride contamination, in conjunction with the nitric acid $\left(\mathrm{HNO}_{3}\right)$ used to dissolve the hydroxide precipitate, created a corrosive mixture that was detrimental to the stainless-steel, glove-box surfaces.

An alternate method was therefore sought that would reduce the potential for process operator radiation exposures and that would minimize corrosion to the process equipment and glove-box surfaces.

The developed cation exchange process utilizes the high absorption of americium and plutonium $\left(K_{\mathrm{D}}=10^{4}\right)$ on cation resin in addition to the low absorption of magnesium $\left(\mathrm{K}_{\mathrm{D}}=88\right)$, potassium $\left(K_{D}=29\right)$, and sodium $\left(K_{D}=12\right)$. The approximate MSE residue composition is 43 weight percent potassium chloride $(\mathrm{KCl}), 44$ weight percent sodium chloride $(\mathrm{NaCl}), 7.6$ weight percent magnesium chloride $\left(\mathrm{MgCl}_{2}\right), 5$ weight percent plutonium chloride $\left(\mathrm{PuCl}_{3}\right)$, and 0.3 weight percent americium chloride $\left(\mathrm{AmCl}_{3}\right)$.

The salt residue is initially dissolved in $1 \mathrm{M}$ hydrochloric acid $(\mathrm{HCl})$, filtered, and passed over a bed of cation resin (Dowex* $50 \times 8 \mathrm{H}^{+}$form). The chloride anion will not load onto the cation resin, so the chloride separation is easily accomplished. The plutonium and americium are eluted next using strong nitric acid (7M). The plutonium and americium are separated using an anion exchange process in which the plutonium forms an hexanitrato complex that loads onto anion resin. The americium passes through the anion resin bed and is recovered by another process. ${ }^{3}$

The developed ion exchange process has been installed in the Rocky Flats recovery operation. The process has been demonstrated previously using production sized equipment. The procedure and data from the production demonstration runs are discussed in this report.

\footnotetext{
*Trademark of The Dow Chemical Company, Midland, Michigan.
} 


\section{EXPERIMENTAL}

\section{Equipment}

The equipment used in demonstration runs for dissolution of chloride salt consisted of four-litre glass beakers and a Thermolyne stirring hot plate. The cation column was a 6 -inch-diameter by $24-$ inch-high glass column filled with 11.1 litres of Dowex $50 \times 8$ cation resin $\left(\mathrm{H}^{+}\right.$form). The anion column was a 4 -inch-diameter by 12 -inch-high glass column filled with 2.5 litres of Dowex 1-X4 anion resin (nitrate form). The solutions were pumped through the resin columns using a Masterflex No. 701 / tubıng pump. T'Te flow was regulated with a Masterflex pump controller.

\section{Procedure}

Routine molten salt extraction residues were used throughout the demonstration runs. The MSE residues were weighed out in 1050-gram batches. Each batch was placed in a 4-litre beaker with 2.9 litres of $1 \mathrm{M} \mathrm{HCl}$ and heated to a boiling temperature. After boiling for 15 minutes, the solution was allowed to cool to $40^{\circ} \mathrm{C}$ and was filtered through Whatman No. 52 filter paper. The filter residue was washed with 100 millilitre. of water, dried, weighed and sampled for plutonium and americium content and for idcntification. The resulting filtrate ( 3.5 litre) was diluted to 7.0 litre with water and sampled. The diluted feed solution was passed over the previously conditioned cation column at a 15 litre per hour flow rate. The cation column was previously conditioned by passing 18 litres of $7 \mathrm{M} \mathrm{HNO}_{3}$ over the cation resin followed hy 18 litres of water. $\Lambda$ pproximatcly 35 litres of adjusted feed were passed through the cation column before washing commenced. Cation effluent line samples were taken at 4-litre increments to determine the disposition of the molten salt constituents. The cation column was then washed with 22 litres (2 column volumes) of water to remove the chlorido impurity. The effluent and wash were composited and then sampled.

The cation column was next eluted using 22 litres ( 2 colunn vulumes) of $7.5 \mathrm{M} \mathrm{HNO}_{3}$ followed by 11 litres ( 1 column volume) of water wash. The eluate and water wash were combined and sampled for a complete analysis of all salt consituents. The water-washed cation column was then ready for loading the next batch of cation feed.

The cation eluate acidity was increased to $7.2 \mathrm{M}$ by adding an appropriate volume of concentrated nitric acid. The adjusted eluate was then passed over the anion exchangc column to separate the plutonium and americium. The anion resin had

FICURE 1. Process Fluwshteet.

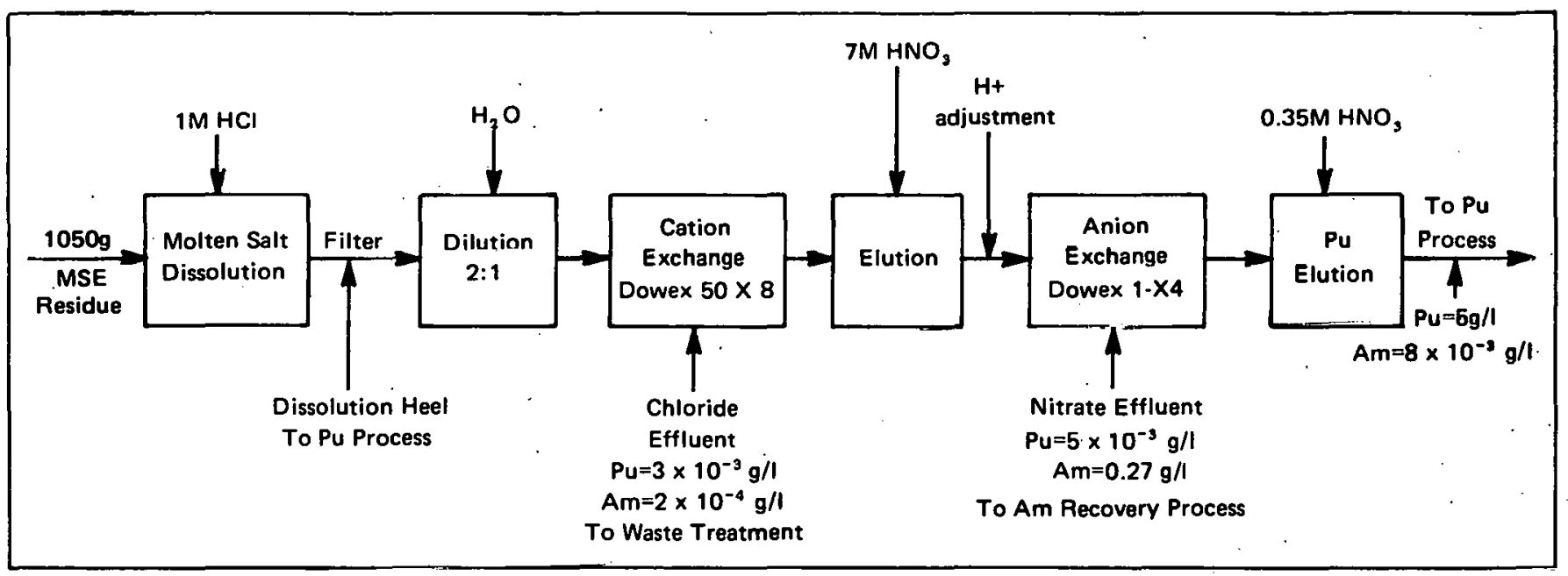


been conditioned previously by passing 5 litres ( 2 column volumes) of $7.2 \mathrm{M} \mathrm{HNO}_{3}$ through the anion column. The loaded column was washed with 7.5 litres ( 3 column volumes) of $7.2 \mathrm{M} \mathrm{HNO}_{3}$. The americium-bearing effluent was sampled and set aside for future americium recovery. The plutonium was eluted from the anion column with 12.5 litres ( 5 column volumes) of $0.35 \mathrm{M} \mathrm{HNO}_{3}$ and returned to the process stream.

\section{RESULTS}

A series of eight demonstration runs were made using the developed procedure. A process flow sheet for the developed process is shown in Figure 1. All liquid actinide analyses were accomplished by radiometric methods.

\section{Feed Composition}

Analytical results on the eight batches of cation feed showed the composition to be fairly constant. An average cation feed composition for the eight runs is shown in Table 1.

The heel resulting from the MSE residue dissolution had an average weight of 2.2 grams per kilogram $(\mathrm{g} / \mathrm{kg})$ of MSE residue. The insoluble residue was identified by $\mathrm{X}$-ray diffraction techniques as plutonium oxide $\left(\mathrm{PuO}_{2}\right)$ and americium oxide $\left(\mathrm{AmO}_{2}\right)$ with trace amounts of unidentifiable materials. Analysis by emission and X-ray fluorescence spectrographic methods gave the composition shown in Table 2.

\section{Cation Effluents}

The cation effluent analyses for the eight demonstration runs are shown in Table 3 . The average plutonium and americium concentrations were $3.5 \times 10^{-3}$ grams per litre $(\mathrm{g} / 1)$ and $1.8 \times 10^{-4} \mathrm{~g} / \mathrm{l}$, respectively. The cation effluent profile obtained from line sample analyses showed the plutonium and americium concentration increased only when breakthrough was approached. A plot of the effluent volume versus the plutonium and americium concentration is shown in Figure 2.

\section{Cation Eluate}

The analyses on the eight cation eluates are shown in Table 4. The average eluate contained $3.5 \mathrm{~g}$ plutonium and $0.25 \mathrm{~g}$ americium per litre of eluate with no detectable chloride in any of the eluates. The cation eluate analyses gave a good material balance, which showed that $80 \%$ of the magnesium, potassium, and sodium had been separated from the americium and plutonium. The plutonium and americium recoveries were $99.8 \%$ and $99.9 \%$, respectively. A material balance for the entire. eight runs is shown in Table 5.

Two elutions were made where the americium and plutonium elutions were observed. Figure 3 shows the elution of the two actinides versus the
TARI.E 1. Cation Feed Composition.

\begin{tabular}{lc} 
Element & $\begin{array}{c}\text { Average Concentration } \\
(\mathrm{g} / \mathrm{l})\end{array}$ \\
\cline { 3 - 3 } Plutonium & 4.02 \\
Americium & 0.40 \\
Magnesium & 2.1 \\
Potassium & 18.6 \\
Sndinm & 12.5 \\
Chlorine & 58.8
\end{tabular}

TABLE 2. Dissolution Heel Analysis.

\begin{tabular}{lcc}
\multicolumn{1}{c}{ Element } & \multicolumn{2}{c}{ Concentration } \\
\cline { 3 - 4 } Plutonium & \multicolumn{2}{c}{$0.23 \mathrm{~g} / \mathrm{g}$} \\
Americium & \multicolumn{2}{c}{$0.29 \mathrm{~g} / \mathrm{g}$} \\
Copper & 600 & $\mu \mathrm{g} / \mathrm{g}$ \\
Iron & 1000 & $\mu \mathrm{g} / \mathrm{g}$ \\
Potassium & $500 u 0$ & $\mu \mathrm{g} / \mathrm{g}$ \\
Lead & 50 & $\mu \mathrm{g} / \mathrm{g}$
\end{tabular}


volume of $7.5 \mathrm{M} \mathrm{HNO}_{3}$ eluant. The elution data showed the actinides were $95 \%$ eluted with 28 litres of eluant ( 2.5 column volumes).

\section{Cation Resin Capacity}

The cation exchange capacity determinations showed a cation resin capacity of 473 grams molten salts per litre of cation resin. Good agreement was obtained for two runs, and a well defined actinide breakthrough was observed (see Figure 2).

\section{DISCUSSION}

\section{Cation Feed}

The demonstration runs showed that the MSE residues can be processed efficiently using the developed cation exchange procedure. Analytical results on the feed solutions gave a composition that compared favorably with the theoretical composition. The theoretical composition is the MSE residue composition as produced by the MSE process under optimum conditions. The sodium and chloride values were slightly low but were within the accuracy limits of the analytical procedure. All other values were nearly exact.
TABLE 3. Cation Effluent Analyses.

\begin{tabular}{ccc} 
RuII & $\begin{array}{c}\text { Plutonium } \\
\text { Concentration } \\
(\mathrm{E} / 1)\end{array}$ & $\begin{array}{c}\text { Americium } \\
(\mathrm{g} / \mathrm{l})\end{array}$ \\
\cline { 2 - 2 } 2 & $4.1 \times 10^{-3}$ & $5.8 \times 10^{-4}$ \\
2 & $1.9 \times 10^{-3}$ & $3.8 \times 10^{-5}$ \\
3 & $5.3 \times 10^{-3}$ & $5.2 \times 10^{-4}$ \\
4 & $4.1 \times 10^{-3}$ & $5.1 \times 10^{-5}$ \\
5 & $4.0 \times 10^{-3}$ & $2.7 \times 10^{-5}$ \\
6 & $5.1 \times 10^{-3}$ & $1.5 \times 10^{-4}$ \\
7 & $2.3 \times 10^{-3}$ & $3.5 \times 10^{-5}$ \\
8 & $\frac{1.7 \times 10^{-3}}{4.5 \times 10^{-3}}$ & $\frac{4.6 \times 10^{-5}}{1.8 \times 10^{-4}}$
\end{tabular}

\section{Molten Salt Extraction Dissolution Heel}

The insoluble residue removed from the salt dissolution was only 0.22 weight percent of the total input. $\mathrm{X}$-ray diffraction analysis showed the residue was composed of $\mathrm{PuO}_{2}$ and $\mathrm{AmO}_{2}$. Small amounts of $\mathrm{PuO}_{2}$ and $\mathrm{AmO}_{2}$ were expected in the MSE residue because of oxidation of the chloride salts in the MSE process. 'These oxides were not expected to dissolve in $1 \mathrm{M}$ hydrochloric acid $(\mathrm{HCl})$. Their removal was accomplished easily using a one-micron filter paper. The insoluble heel was transferred to the plutonium processing stream for plutonium recovery.

\section{Cation Effluents}

The cation column effluents were well below the discard limit set for ion column effluents (i.e., $1.2 \times 10^{-2}$ grams of plutonium per litre of solution). The cation effluents contained an

FIGURE 2. Cation Effluont Profilc.

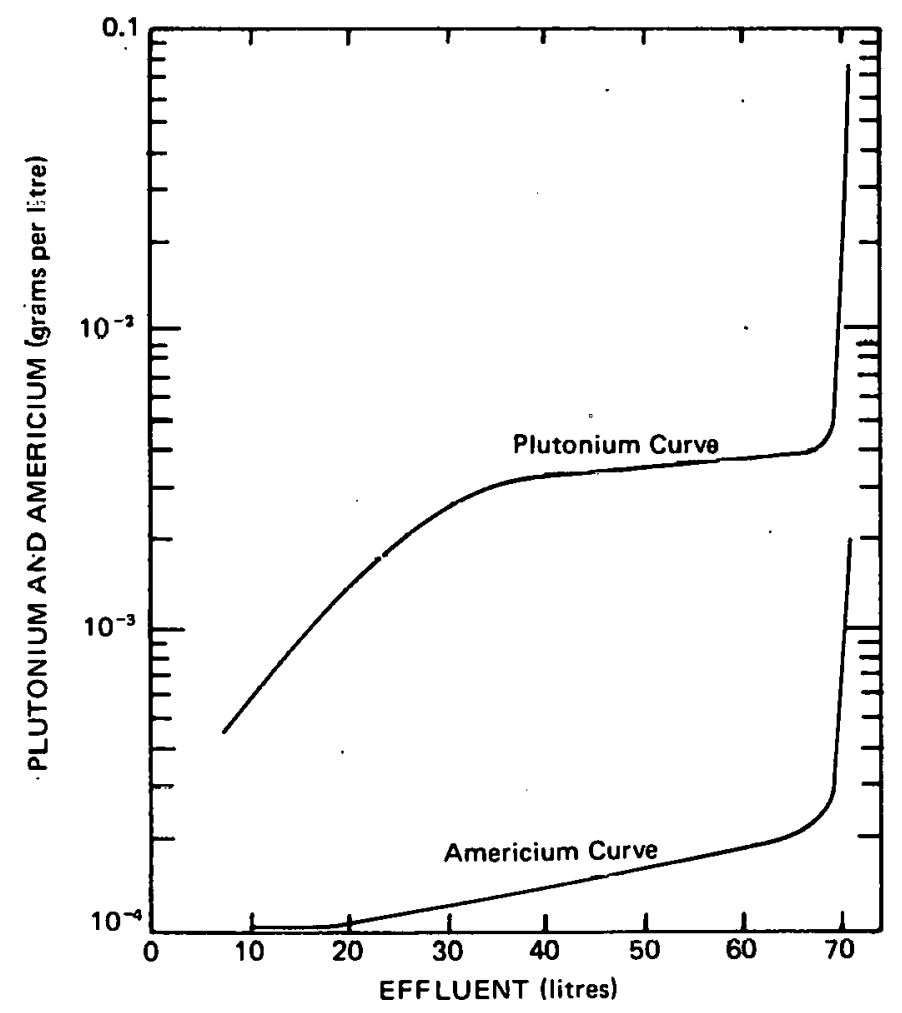


average of $3.5 \times 10^{-3} \mathrm{~g} / \mathrm{l}$ plutonium and $1.8 \times 10^{-4} \mathrm{~g} / \mathrm{l}$ americium with $80 \%$ of the magnesium, potassium, and sodium being discarded in the cation effluent. More important than the cation impurity removal was the total removal of the corrosive chloride contamination.

Several attempts were made at lowering the plutonium and americium content in the effluents. Various dilutions of the cation feed solutions were tried in an effort to improve the process. No improvements were noted for dilutions greater than two to one. A dilution of at least 2:1 is necessary to obtain quantitative loading of the two actinides. The dilution is necessary to reduce the cationic impurity (sodium and potassium) concentration to below 0.5 molar. Care must be exercised to prevent oxidation of the plutonium from the desired trivalent state to the tetravalent state. Tetravalent plutonium will form an anionic chloride complex, plutonium hexachloride $\left(\mathrm{PuCl}_{6}^{\overline{6}}\right)$, which will prevent quantitative loading of the plutonium. If oxidants (i.e., $\mathrm{HNO}_{3}$ ) are mistakenly added to the cation feed, a reductant [i.e., hydroxylamine hydrochloride $\left.\left(\mathrm{NH}_{2} \mathrm{OH} \cdot \mathrm{HCl}\right)\right]$ must be added to reduce any tetravalent plutonium to the required trivalent state. $^{4}$

Duplicate runs were made to determine the capacity of Dowex $50 \times 8$ cation resin for the molten salt cations. A capacity value of 473 grams MSE residues per litre of resin was found with good agreement noted for the two runs.

Attempts at selectively eluting the plutonium, using various strengths of nitric acid, were unsuccessful. At acid normalities greater than $0.7 \mathrm{M}$, elution of

TABLE 4. Cation Eluate Analyses (g/l).

\begin{tabular}{|c|c|c|c|c|c|c|}
\hline Run & Plutonium & Americium & Magnesium & Potassium & Sodium & $\mathrm{H}^{+}$ \\
\hline 1 & 0.8 & 0.13 & 0.4 & 4.7 & 3.2 & $4.8 \mathrm{M}$ \\
\hline 2 & 0.8 & 0.10 & 0.4 & 3.5 & 4.5 & $6.7 \mathrm{M}$ \\
\hline 3 & 1.3 & 0.13 & 0.8 & 4.4 & 4.6 & $5.6 \mathrm{M}$ \\
\hline 4 & 3.8 & 0.32 & 0.7 & 4.4 & 4.4 & $5.6 \mathrm{M}$ \\
\hline 5 & 5.5 & 0.40 & 0.4 & 3.0 & 4.7 & $6.6 \mathrm{M}$ \\
\hline 6 & 4.0 & 0.31 & 0.4 & 3.7 & 2.0 & $5.9 \mathrm{M}$ \\
\hline 7 & 5.0 & 0.32 & 0.3 & 3.5 & 2.7 & $5.6 \mathrm{M}$ \\
\hline 8 & 3.0 & 0.30 & 0.4 & 4.2 & 2.6 & $5.6 \mathrm{M}$ \\
\hline Average & 3.5 & 0.25 & 0.5 & 4.2 & 3.2 & $5.8 \mathrm{M}$ \\
\hline
\end{tabular}

TABLE 5. Material Balance.

\begin{tabular}{lrrrrr} 
Element & $\begin{array}{c}\text { Input } \\
(\mathrm{g})\end{array}$ & & $\begin{array}{c}\text { Discarded } \\
\text { in Effluent } \\
(\mathrm{g})\end{array}$ & $\begin{array}{c}\text { Recovered } \\
\text { in Eluate } \\
(\mathrm{g})\end{array}$ & $\begin{array}{c}\text { Recovered } \\
\text { in Eluate } \\
(\%)\end{array}$ \\
\cline { 1 - 1 } Plutonium & 831.7 & 1.44 & 830.3 & 99.8 \\
Americium & 58.5 & 0.08 & 58.4 & 99.9 \\
Magnesium & 462.0 & 400.0 & 62.0 & 13.5 \\
Potassium & 5475.0 & 4018.0 & 1456.0 & 26.6 \\
Sodium & 4158.0 & 3376.0 & 782.0 & 18.8 \\
Chlorine & 12636.0 & 12636.0 & 0 & 0
\end{tabular}

FIGURE 3. Americium and Plutonium Elution Curve.

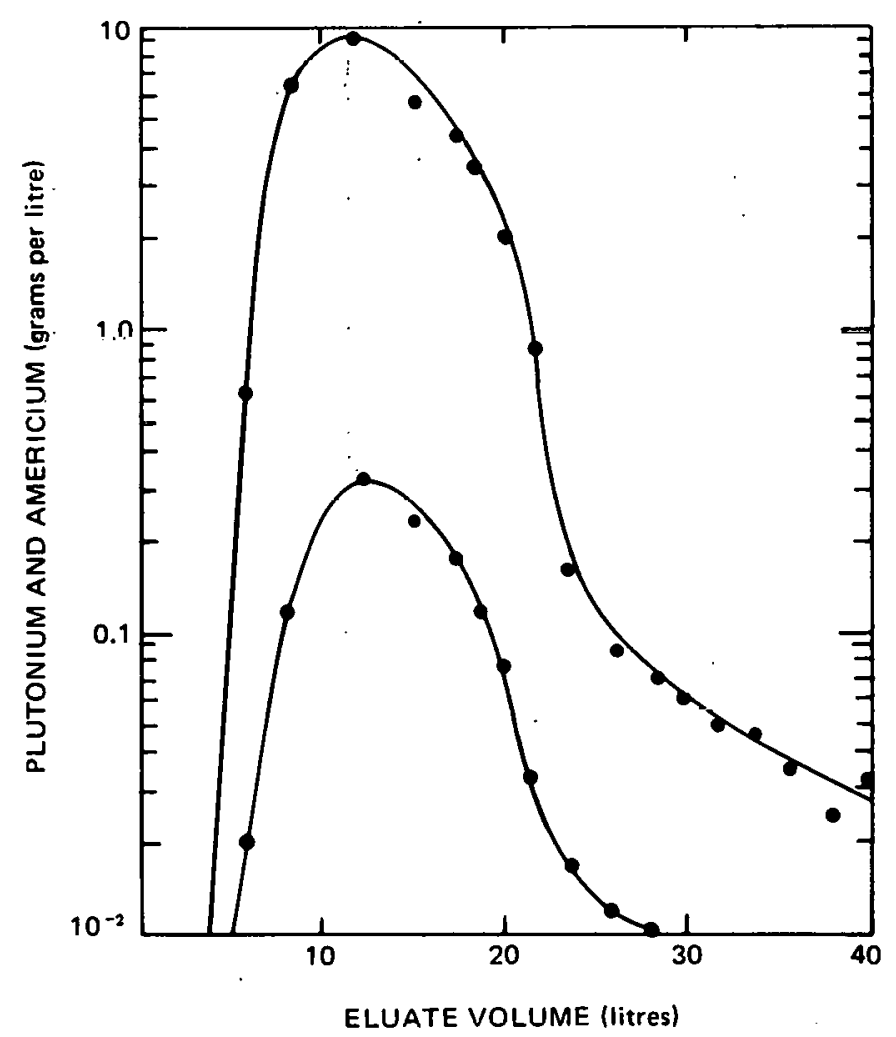


both actinides occurred. Attempts at selective elution using sodium nitrate ( $2 \mathrm{M}$ and $5 \mathrm{M}$ ) gave similar results. In high concentrations of nitrate ion, the plutonium hexanitrato complex did form, but the high concentrations of sodium ion caused the americium to elute along with the plutonium.

The cation eluate analyses showed excellent plutonium and americium recoveries $(99.8 \%$ and 99.9\%). The chloride decontamination factor for the eight runs was greater than 1500 . The plutonium and americium were separated next using the anion exchange technique where plutonium forms a hexanitrato complex in $7 \mathrm{M} \mathrm{HNO}_{3}$ and absorbs on the anion resin. Americium does not absorb; it passes through the resin bed with the effluent. The anion effluent and eluate analyses showed the separation worked well. The plutonium decontamination factor from the americium was 660 ; the americium decontamination factor from the plutonium was 34 .

The plutonium-americium separation, using anion exchange, performed well. The americium concentration in the plutonium eluate was acceptable to the routine plutonium stream, and the plutonium content in the anion effluent was acceptable for the americium recovery process. The americiumbearing effluent and the plutonium-eluate analyses are shown in Table 6 .

In summary, the cation exchange process is capable of processing MSE residues with minimal process operator manipulations. The process produces a plutonium-americium-nitric acid solution free of any chloride contamination that will reduce glove-box and equipment corrosion. The MSEresidue processing rate is also expected to increase
TABLE 6. Anion Exchange Separation. $\frac{\text { Anion Effluent Analysis (g/l) }}{\text { Plutonium } 5.3 \times 10^{-3}}$

Americium 0.27
Anion Eluate Analysis (g/l)

Plutonium 5.6

Americium 0.008 because of a shortened process flow. The developed process has been made into a full-scale production process and is currently being used to process MSE residues.

\section{REFERENCES}

1. J. B. Knighton, J. L. Long, R. C. Franchini, R. G. Auge, J. C. Brown, and F. G. Meyer.

- A Batch Two-Stage Countercurrent Mode for Liquid Plutonium-Molten Salt Extraction of Americium. RFP-1875. Dow Chemical U.S.A., Rocky Flats Division. July 31, 1973.

2. C. C. Perry and V. A. Casaday. Dow Chemical U.S.A., Rocky Flats Division. Personal communication. March 17, 19\%2.

3. V. A. Ryan and J. W. Pringlc. Prcparation of Pure Americium. RFP-130. The Dow Chemical Company, Rocky Flats Division. January 8 , 1960.

4. D. E. Kudera and R, H. Guyer. Plutonium and Americium Recovery from a Chloride-Salt Matrix. RFP-1642. Dow Chemical U.S.A., Rocky Flats Division. June 4, 1971. 